\title{
How to Prepare Disaster Mitigation Knowledge for Prospective Teachers in Elementary School?
}

\author{
Eddy Noviana 1, Otang Kurniaman ${ }^{2}$, Nugraheti Sismulyasih Sb 3, \\ Sri Dewi Nirmala 4, Ratna Sari Dewi 5
}

DOI: $10.35445 /$ alishlah.v13i2.496

\section{Article Info}

Keywords:

Knowledge of disaster mitigation;

Prospective elementary

school teachers

\begin{abstract}
Knowledge of disaster mitigation is one of the must-have primary school teacher candidates. The research tries to identify the knowledge of prospective elementary school teachers about natural, non-natural, and social disaster mitigation. In this study, the teacher candidates referred to are primary school teacher of education department students at the University of Riau. The research method used is qualitative research. The research subjects were 69 elementary school teacher candidates. The data on disaster mitigation knowledge collected were: (a) definition of disaster mitigation; (b) type of disaster; and (c) disaster management procedures. The research instrument used was a list of interviews. Data collection using interview techniques, while data analysis using qualitative data analysis techniques. The results showed that the knowledge of prospective primary school teachers about the term disaster mitigation mainly stated that the notion of disaster mitigation is an effort to reduce or minimize the risk and impact of a disaster. The knowledge of prospective elementary school teachers about disasters has mentioned various types of natural and non-natural disasters. The knowledge of prospective school teachers in explaining disaster management procedures has provided answers about various disaster management procedures. The disaster management procedure that is most often referred to is flood disaster management. This study concludes that knowledge about disaster mitigation for prospective elementary school teachers is quite good.
\end{abstract}

\begin{abstract}
Abstrak
Pengetahuan tentang mitigasi bencana merupakan salah satu yang harus dimiliki oleh calon guru sekolah dasar. Penelitian mencoba mengidentifikasi pengetahuan calon guru sekolah dasar tentang mitigasi bencana alam, non alam dan sosial. Calon guru yang dimaksud dalam penelitian ini adalah mahasiswa program studi pendidikan guru sekolah dasar di Universitas Riau. Metode penelitian yang digunakan adalah penelitian kualitatif. Subjek penelitian adalah calon guru sekolah dasar yang berjumlah 69. Data pengetahuan mitigasi bencana yang dikumpulkan adalah: (a) definisi mitigasi bencana; (b) jenis bencana; dan (c) prosedur manajemen bencana. Instrumen penelitian yang digunakan adalah daftar wawancara. Pengumpulan data menggunakan
\end{abstract}

Kata kunci:

Pengetahuan mitigasi bencana; Calon guru sekolah dasar

\footnotetext{
${ }^{1}$ Universitas Riau, Pekanbaru, Indonesia Email: eddy.noviana@lecturer.unri.ac.id 2 Universitas Riau, Pekanbaru, Indonesia Email: otang.kurniaman@lecturer.unri.ac.id 3 Universitas Negeri Semarang, Semarang, Indonesia Email: nugraheti@mail.unnes.ac.id 4 Universitas Pakuan, Bogor, Indonesia Email: nirmalasridewi73@gmail.com 5 Universitas Sultan Ageng Tirtayasa, Serang, Indonesia Email: ratna@untirta.ac.id
} 
teknik wawancara, sedangkan analisis data menggunakan teknik analisis data kualitatif. Hasil penelitian menunjukkan bahwa pengetahuan calon guru sekolah dasar tentang istilah mitigasi bencana sebagian besar menyatakan bahwa pengertian mitigasi bencana merupakan upaya untuk mengurangi atau meminimalkan risiko dan dampak bencana. Pengetahuan calon guru sekolah dasar tentang jenis bencana telah menyebutkan berbagai jenis bencana, baik bencana alam maupun non bencana alam. Pengetahuan calon guru sekolah dalam menjelaskan prosedur penanggulangan bencana telah memberikan jawaban tentang berbagai jenis prosedur penanggulangan bencana. Prosedur penanggulangan bencana yang paling sering disebut adalah penanggulangan bencana banjir. Kesimpulan dari penelitian ini adalah pengetahuan tentang mitigasi bencana bagi calon guru sekolah dasar adalah cukup baik.

\section{INTRODUCTION}

Prospective teachers in Indonesia very much need knowledge of disaster mitigation. Indonesia is a region with a high enough risk of disasters. The territory of Indonesia is an archipelagic country that occupies three major world plates that meet each other. The large plates are the Indo-Australian Plate, the Eurasian Plate, and the Pacific Plate (Akbar et al., 2011). Natural disasters have a very complex impact on every aspect of life from an economic, social, and health perspective (Puspita, 2020). Natural phenomena related to the threat of disasters such as tsunami, eruptions, tectonic earthquakes, volcanic earthquakes, tremors, multiphase earthquakes, hot clouds, hot lava, cold lava, lava domes, volcanic ash are increasingly familiar to the public. That is the learning that society receives. People become familiar with the natural environment and its phenomena or symptoms. Natural symptoms in natural disasters do not need to be addressed negatively but should be treated positively.

Disaster mitigation has been carried out to reduce risks and impacts caused by disasters on communities living in vulnerable areas, whether natural disasters, unnatural disasters, or a combination of the two in a country or community (Government Regulation of the Republic of Indonesia Number 24 of 2007). In the context of disasters, there are two types of disasters, namely (1) natural disasters, which are a series of disaster events caused by natural factors, namely in the form of earthquakes, tsunami, volcanic eruptions, floods, droughts, typhoons, and landslides. (2) a social disaster is caused by humans, such as social conflict, community disease, and terror (Utaminingsih \& Hakim, 2015). The cultivation of knowledge in educational principles is inherent in optimizing the role of education in environmental education (Yustina et al., 2010; Yustina \& Kaspin, 2017). Mitigation learning in primary schools is an essential role for teachers and prospective teachers in providing knowledge that involves affective, cognitive, and psychomotor activities related to students' (Mushtaq \& Khan, 2012) daily lives that build knowledge and abilities (Sumarni et al., 2016).

Education in schools by including knowledge to prospective teachers is a positive value about awareness of the vulnerability of the surrounding environment and the risk of experiencing a disaster (Widowati et al., 2021). One of the disasters in Riau Province is that floods and forest fires are always haze disasters every year. Riau Province is a coastal area and waters where there will be tides and ebbs in the sea each year, resulting in rising water levels to the land. Besides that, four large rivers cross, namely the Siak River, Kuantan River, Indragiri River, and River Kampar. Meanwhile, the haze disaster was caused by the dryness of the peatlands caused by the dry season. This knowledge provides awareness to prospective teacher students to include learning material as a form of awareness with its values (Kastolani \& Mainaki, 2018). Knowledge about disaster mitigation has to be obtained through information media or mass media (Haddow, 2008; Mahmoud \& Auter, 2009; Winkellmann, 2012), providing information and interpersonal. However, prospective teachers must be able to filter helpful information for readers. Previous research has shown the preparedness of science education teacher candidates (Fadilah et al., 2021) and high school teachers in the face of earthquakes (Ardiansyah, 2017). However, there has been 
no explanation regarding natural, non-natural, and social disaster preparedness for prospective elementary school teachers. This research tries to identify the knowledge of prospective teachers, especially elementary school teacher candidates, about natural, non-natural, and social disaster mitigation. The teacher candidates referred to in this study are students in the primary school teacher of education study program at the University of Riau. Therefore, it has been hoped that prospective teachers must have the ability to obtain and filter information about disasters and disaster mitigation excellently and comprehensively. It has been hoped that with this ability, prospective teachers will have knowledge content about disaster mitigation which will later be transferred back to students (Mushtaq \& Khan, 2012; Ye et al., 2020).

\section{METHODS}

The research method used is qualitative research. Qualitative research examines natural objects' conditions, where the researcher is a crucial instrument (Sugiyono, 2015). The research subjects were 69 elementary school teacher candidates. The research instrument used was a list of interviews. Interviews conducted with respondents included: (a) knowledge of disaster mitigation; (b) knowledge of the type of disaster; and (c) knowledge of disaster management procedures. Research data collection using interview techniques. Data collection techniques in research have been sourced from interview notes, according to Moleong (2010), who suggests that data using interviews and documents in the field. Data collection aims to provide factual and realistic data that can explain the phenomenon of the research subject-analysis using qualitative data analysis techniques. The analysis technique in qualitative research uses ethnography carried out in natural conditions and factual findings in the field (Creswell, 2010), which states that data analysis is an ongoing process that requires continuous data reflection. The steps taken in analyzing research data are: (a) coding the data, (b) making concepts, (c) creating categories, (d) making assumptions, and (e) draw conclusions.

\section{FINDINGS AND DISCUSSION}

Based on the data collection and processing results carried out in the study, the following is the research data obtained from the results of open questions and interpersonal interviews from respondents, as described below.

\section{Knowledge of the Definition of Disaster Mitigation}

Knowledge of the definition of disaster mitigation is grouped based on the tendency of respondents' answers. The following are the respondents' answers regarding the term or definition of disaster mitigation as an effort to reduce or minimize the risk and impact of disasters as follows:

RPC_O03 answered: "Upaya yang dilakukan untuk mengurangi resiko bencana, sehingga dapat memperkecil jumlah korban atau kerugian akibat bencana (Efforts are made to reduce disaster risk, to minimize the number of victims or losses due to disasters)".

RPC_007 answered: "Mitigasi bencana merupakan upaya yang dilakukan untuk meminimalisir dampak/resiko bencana. Baik berupa upaya pra bencana, saat bencana, dan pasca bencana (Disaster mitigation is an effort made to minimize the impact/risk of a disaster. Both in the form of pre-disaster, during the disaster, and post-disaster efforts)".

RPC_009 answered: "Serangkaian upaya untuk mengurangi resiko bencana, baik melalui pembangunan fisik maupun penyadaran dan peningkatan kemampuan menghadapi ancaman bencana (A series of efforts to reduce disaster risk, both through physical development as well as awareness and increased capacity to face disaster threats)".

RPC_024 answered: "Mitigasi bencana hal atau upaya yang bisa kita lakukan untuk mengurangi resiko bencana (Disaster mitigation is the thing or effort we can do to reduce disaster risk)".

RPC_029 answered: “Usaha-usaha yang dilakukan untuk mengurangi dampak dari terjadi bencana (Efforts are made to reduce the impact of a disaster)”.

Then for respondents' answers regarding the term disaster mitigation as disaster management and prevention are as follows: 
RPC_056 answered: “Merupakan suatu langkah perencanaan terhadap bencana alam agar dapat di atasi supaya tidak menghasilkan dampak yang besar (It is a planning step for natural disasters so that they can be overcome so as not to have a large impact)".

RPC_059 answered: "serangkaian upaya untuk menyekat atau membendung terjadinya bencana (a series of attempts to block or stem a disaster)".

RPC_046 answered: "Mitigasi bencana adalah langkah-langkah atau cara-cara penanganan suatu bencana (Disaster mitigations are the steps or ways of dealing with a disaster)".

For groups of respondents' answers regarding the term disaster mitigation as a person's readiness to face disasters are as follows:

RPC_052 answered: "Mitigasi bencana merupakan rancangan atau pengetahuan dini mengenai tanda tanda akan datangnya sebuah bencana dan cara penanggulangannya (Disaster mitigation is a design or early knowledge of the signs of an impending disaster and how to overcome them)".

RPC_027 answered: "kesiapan seseorang untuk menghadapi bencana (one's readiness for disaster)".

Respondents' answers regarding the term disaster mitigation as an effort to mitigate, reduce risk and impact of disasters as well as one's readiness to face disasters are as follows:

RPC_045 answered: "Mitigasi Bencana merupakan upaya penanggulangan bencana baik sebelum bencana terjadi, ketika bencana terjadi dan sesudah bencana terjadi. Mitigasi bencana bertujuan memberikan pengetahuan kepada masyarakat terkait hal apa saja yang harus dilakukan sebelum, ketika bencana dan sesudah bencana untuk mengurangi dampak kerugian (Disaster Mitigation is a disaster management effort both before a disaster occurs when a disaster occurs and after a disaster occurs. Disaster mitigation aims to provide knowledge to the community regarding what to do before, during a disaster and after a disaster to reduce the impact of losses)".

Respondents' answers regarding the term disaster mitigation as an agency to monitor or predict disasters are as follows:

RPC_047 answered: “Adalah suatu badan yang mengawasi atau memprediksi adanya bahaya atau bencana yang ada di suatu daerah yang diawasi (Is an agency that monitors or predicts the existence of a hazard or disaster in a controlled area)".

The respondent's answer group regarding the answer that they already know the term disaster mitigation but do not understand the meaning of the term disaster mitigation is as follows:

RPC_032 answered: "Saya hanya pernah mendengar, tapi tidak paham maksudnya apa (I've only heard of it, but don't know what it means)".

Meanwhile, the group of respondents' answers regarding whether or not they have never heard of the term disaster mitigation is as follows:

RPC_050 answered: "Saya belum pernah mendengar istilah mitigasi bencana (I have never heard of the term disaster mitigation)".

RPC_069 answered: "Karena tidak pernah mendengar mitigasi bencana (Because never heard of disaster mitigation)."

For groups of respondents' answers regarding not knowing the term disaster mitigation are as follows:

RPC_036 answered: "Karena saya belum mengetahui nya (Because I do not know yet)".

RPC_OO5 answered: "Baru pertama mengetahuinya" (It was the first time I found out)".

Moreover, for the group of respondents' answers regarding not finding out the term disaster mitigation are as follows:

RPC_058 answered: "Karna Saya tidak tahu dan belum mencari tahu (Because I do not know and have not found out)'.

The following are responsive responses regarding the term disaster mitigation, as shown in Table 1 below. 


\begin{tabular}{llcc}
\multicolumn{3}{c}{ Table 1. Respondents' Responses on Disaster Mitigation Terms } \\
\hline $\begin{array}{l}\text { Respondents' } \\
\text { Answers }\end{array}$ & \multicolumn{1}{c}{ Respondents' Answers Classification } & Count & Percentage \\
\hline Yes & $\begin{array}{l}\text { The term disaster mitigation is an effort to reduce or minimize } \\
\text { the risk and impact of a disaster }\end{array}$ & 44 & $63,77 \%$ \\
\hline & $\begin{array}{l}\text { The term disaster mitigation refers to disaster management and } \\
\text { prevention }\end{array}$ & 11 & $15,94 \%$ \\
\hline $\begin{array}{l}\text { The term disaster mitigation refers to one's readiness in facing } \\
\text { disasters }\end{array}$ & 2 & $2,90 \%$ \\
\hline $\begin{array}{l}\text { The term disaster mitigation refers to efforts to overcome, } \\
\text { reduce the risk and impact of disasters and the readiness of a } \\
\text { person in facing disasters }\end{array}$ & 1 & $1,45 \%$ \\
\hline $\begin{array}{l}\text { The term disaster mitigation as an agency to monitor or predict } \\
\text { disasters }\end{array}$ & 1 & $1,45 \%$ \\
\hline $\begin{array}{l}\text { Answer yes, but do not understand the meaning of the term } \\
\text { disaster mitigation }\end{array}$ & 1 & $1,45 \%$ \\
\hline Not yet and never heard of the term disaster mitigation & 5 & $7,25 \%$ \\
\hline $\begin{array}{l}\text { do not know the definition of disaster mitigation } \\
\text { No }\end{array}$ & 3 & $4,35 \%$ \\
\hline Number looking into the term disaster mitigation & $\mathbf{6 9}$ & $\mathbf{1 0 0 , 0 0 \%}$ \\
\hline
\end{tabular}

Based on table 1 above, to determine the extent of the respondent's knowledge of the definition of disaster mitigation with the respondent's answer, yes or no. The number of respondents who answered yes was 60 people, and the number of respondents who answered no was nine people. The knowledge of prospective elementary school teachers about the term disaster mitigation to minimize the risk and impact of disasters has been answered by 44 respondents with a percentage of $63.77 \%$. Knowledge of the term disaster mitigation as disaster management and prevention obtained 11 respondents with $15.94 \%$. Knowledge of the term disaster mitigation as a person's readiness in facing disasters with a total of 2 respondents gets a percentage of $2.90 \%$. One respondent answered the understanding of disaster mitigation as community preparedness in facing disasters, risk reduction, and disaster impact, getting a percentage of $1.45 \%$. Knowledge of disaster mitigation as an agency to monitor or predict disasters with one person obtains a percentage of $1.45 \%$. Respondents answered that they had heard the term disaster mitigation but did not understand. There was one person (1.45\%). The number of respondents who had never heard of the term disaster mitigation was five people (7.25\%). Respondents who did not know the term disaster mitigation were three people (4.35\%). Meanwhile, the number of respondents who answered that they had never heard of disaster mitigation was one person (1.45\%).

Based on the information described above, it has been seen that the knowledge of prospective primary school teachers about the term disaster mitigation has mentioned chiefly the definition of disaster mitigation as an effort to reduce or minimize the risk and impact of disasters (Tuswadi and Hayashi, 2014). That indicates that the knowledge of the term disaster mitigation from elementary school teacher candidates is quite good. With this knowledge, prospective teachers can carry out an analysis of conceptual studies of disaster mitigation (Weichselgartner \& Patrick, 2015) to transfer knowledge of disaster mitigation through the socialization process so that it can become one of the teachers' abilities in providing the concept of disaster mitigation in learning (Yustina \& Kapsin 2017).

\section{Knowledge of Types of Disasters}

Respondent's knowledge of the types of disasters is natural disasters and non-natural disasters. Respondents' natural disasters were a flood, forest, and land fire, earthquake, tsunami, landslides, and tornado disasters. Meanwhile, non-natural disasters answered by respondents were covid-19. The following are types of natural disasters and non-natural disasters that respondents answered:

RPC_o6o answered: "Gempa bumi, tsunami, banjir, tanah longsor, kekeringan, angin kencang, kebakaran hutan dan lahan, gelombang pasang, letusan gunung berapi dan wabah penyakit 
(Earthquakes, tsunami, floods, landslides, droughts, strong winds, forest and land fires, tidal waves, volcanic eruptions and disease outbreaks)".

RPC_028 answered: "Gempa bumi, tsunami, longsor, banjir, gunung meletus dan puting beliung (Earthquakes, tsunami, landslides, floods, volcanoes and tornadoes)".

RPC_O03 answered: "Banjir, tsunami, kebakaran hutan atau lahan, wabah penyakit covid-19, dll (Floods, tsunami, forest or land fires, covid-19 outbreaks, etc.)".

RPC_042 answered: "Gempa bumi, banjir, tsunami, gunung meletus, tanah longsor (Earthquakes, floods, tsunami, volcanic eruptions, landslides)".

RPC_028 answered: "Gempa bumi, tsunami, longsor, banjir, gunung meletus dan puting beliung (Earthquakes, tsunami, landslides, floods, volcanoes and tornadoes)".

RPC_044 answered: "Banjir, tsunami, gempa, tanah longsor, gunung meletus (Floods, tsunami, earthquakes, landslides, volcanoes eruption)".

For those who did not provide answers regarding the following types of disasters:

RPC_050: tidak menjawab (no answer).

RPC_034: tidak menjawab (no answer).

Respondents' responses about the types of disasters have seen in Table 2 below.

Table 2. Respondents' Responses on Types of Disasters

\begin{tabular}{|c|c|c|c|}
\hline $\begin{array}{l}\text { Respondents' } \\
\text { Answers }\end{array}$ & Respondents' Answers Classification & Count & Percentage \\
\hline Yes & $\begin{array}{l}\text { The types of disasters answered by the respondents were natural } \\
\text { disasters and non-natural disasters. Natural disasters answered } \\
\text { respondents were flood disasters, forest, and land fire disasters, } \\
\text { earthquake disasters, tsunami disasters, landslides, tornado } \\
\text { disasters. Meanwhile, non-natural disasters answered by } \\
\text { respondents were covid-19. }\end{array}$ & 60 & $86,96 \%$ \\
\hline No & Does not provide answers regarding the type of disaster & 9 & $13,04 \%$ \\
\hline Number of Res & pondents & 69 & $100,00 \%$ \\
\hline
\end{tabular}

Based on table 2 above, to determine the extent of the respondent's knowledge of the type of disaster with the respondent's answer, yes or no. Yes, the number of yes replies was 60 people, with $86.96 \%$, and nine people receiving no answers with $13.04 \%$. Knowledge about the types of disasters mentioned is flood disasters, forest, and land fire disasters, earthquake disasters, tsunami disasters, landslides, tornadoes, natural disasters, non-natural disasters, social disasters, covid-19 outbreaks, volcanic eruptions, haze disaster, geological disaster, hydrometeorological disaster, drought, hail, abrasion, and tidal waves, totalling 60 people with a percentage of $86.96 \%$. Nine respondents did not provide answers related to the type of disaster, with a percentage of $13.04 \%$.

From the aspect of knowledge about the types of disasters, it has presented that the knowledge of prospective elementary school teachers has mentioned various natural and nonnatural disasters. The types of disasters mentioned are flood disasters, forest and land fire disasters, earthquake disasters, tsunami disasters, landslides, tornadoes, natural disasters, nonnatural disasters, social disasters, covid-19 outbreaks, mountain disasters. eruption, haze disaster, geological disaster, hydrometeorological disaster, drought, hail, abrasion, and tidal waves. Knowing the types of disasters from prospective elementary school teachers is the basis for learning about disaster mitigation (Asfani et al., 2016).

\section{Knowledge of Disaster Management Procedures}

The knowledge of prospective primary school teachers about disaster management procedures is as follows.

Knowledge of forest fire mitigation procedures is as follows:

RPC_oo1 answered: "Bencana: karhutla. Sebelum: tidak membakar hutan dan lahan. Saat: memberitahukan petugas pemadam kebakaran segera, menggunakan masker. Setelah: waspada terhadap kebakaran susulan (Disasters: Forest and land fires. Before: not burning forests and land. When: notifying firefighters immediately, wearing a mask. After: alert to followup fires)". 
The answers to the flood disaster mitigation procedures are as follows:

RPC_002 answered: "Bencana: banjir, sebelum: tidak buang sampah ke sungai, pengerukan sungai, tidak membangun rumah dipinggir sungai, saat: matikan listrik, mengungsi ke tempat aman, setelah: bersihkan rumah, waspada terhadap binatang berbisa, waspada jika terjadi banjir susulan (Disaster: flood, before not throwing garbage into the river, dredging the river, not building a house beside the river, when: turning off the electricity, evacuating to a safe place, after cleaning the house, being aware of poisonous animals, being alert in case of further flooding)".

RPC_013 answered: "Banjir. Sebelum: Membuat sumur resapan, membersihkan selokan, tidak menebang hutan atau pohon secara ilegal dan membuang sampah pada tempatnya. Saat: membersihkan bekas bencana banjir, menyediakan air bersih, dan menyediakan bahan pangan. Setelah: meningkatkan upaya menjaga kebersihan lingkungan, membersihkan selokan, menanaman pohon kembali, dan penyuluhan untuk info mengenai bagaimana cara mengatasi dan menjaga lingkungan agar tidak terjadi bencana banjir (Flood. Before: Making infiltration wells, cleaning gutters, not cutting down forests or trees illegally and disposing of garbage in its place. When: cleaning floods, providing clean water, and providing food. After: increasing efforts to maintain environmental cleanliness, cleaning gutters, replanting trees, and counselling for information on how to deal with and protect the environment so that floods do not occur)".

RPC_O25 answered: "bencana banjir, jika membuang sampah sembarangan jika hujan turun sampah tersebut menyebabkan selokan tersumbat, jadi jangan buang sampah sembarangan. Melakukan persiapan evakuasi, menyiapkan perbekalan sekurang-kurangnya tiga hari untuk menghadapi bencana banjir. Saat terjadi banjir menyelamatkan diri ke tempat yang lebih tinggi, simak informasi dari berbagai media, matikan semua jaringan listrik setelah ada petunjuk dari pihak berwenang. Setelah terjadi bencana hindari air banjir karena kemungkinan tercampur zat-zat berbahaya, waspada listrik konslet, jangan melewati daerah yang airnya baru surut karena jalan bisa saja keropos dan lain-lain (flood disaster, if littering if it rains the garbage will cause the gutter to become clogged, so don't litter. Make evacuation preparations, prepare supplies at least three days to deal with floods. When a flood occurs, save yourself to a higher place, listen to information from various media, turn off all power lines after instructions from the authorities. After a disaster, avoid floodwater because it may be mixed with hazardous substances, be aware of the short circuit, do not pass through areas where the water has just receded because the roads may become porous and others)".

The answers to the tsunami disaster mitigation procedures are as follows:

RPC_056 answered: "Bencana: Tsunami. Sebelum: membuat sebuah alat pendeteksi air, yang alat ini akan memberikan peringatan kalau akan ada tsunami yang akan datang. Saat: memberikan arah Jalan evakuasi. Setelah: membuat posko tempat tinggal sementara (Disaster: Tsunami. Before: making a water detector, this tool will give a warning when a tsunami is coming. When: providing directions for the evacuation road. After: establishing a temporary shelter post)".

The answers to the landslide disaster mitigation procedures are as follows:

RPC_048 answered: "Bencana: tanah longsor. Sebelum: jangan menebang pohon di daerah rawan tanah longsor seperti perbukitan. Saat: segera cari tempat untuk menyelamatkan diri atau waspada saat hujan akan turun, karena hujan juga dapt menyebabkan tanah longsor. Setelah: tanam lebih banyak pohon untuk menopang tanah agar tidak mudah longsor (Landslide disaster. Before: do not cut trees in areas prone to landslides such as hills. When: immediately find a place to save yourself or be alert when it will rain because rain can also cause landslides. After: planting more trees to support the soil so that it doesn't slide easily)".

RPC_010 answered: "Bencana: Tanah longsor. Sebelum terjadinya longsor alangkah baiknya kita menanggulangi dengan cara membuat semacam terasiring dan tidak menebang pohon sembarangan, saat terjadi bencana menjauhilah dari tempat tersebut, setelah terjadi bencana, setelah terjadi bencana lakukanlah penanaman pohon diatas sisa sisa longsor tersebut (Landslide disaster. Before the occurrence of landslides, it would be better if we overcome them by making a kind of terrace and not cutting trees carelessly, when a disaster occurs stay away from that place, after a disaster, after a disaster, plant trees on top of the rest of the landslide)".

The answers to the COVID-19 disaster mitigation procedures are as follows:

RPC_Oo3 answered: "Bencana: wabah penyakit covid 19, Sebelum: mensosialisasikan tentang penyakit covid 19 kepada masyarakat baik gejalanya, cara mencegah penularanya dan resiko 
atau bahaya covid 19, Saat: melakukan upaya pencegahan atau memutus rantai penyebaran covid 19, dengan menerapkan gaya hidup sehat, mengurangi kegiatan di luar rumah atau berkumpul di tempat umum, sering cuci tangan, memakai masker saat keluar rumah dan ikut serta dalam membantu melawan dan menanggulangi covid 19 dengan memberikan bantuan material dan non material, Setelah: tetap berupaya mencegah penyebaran covid 19, menerapkan gaya hidup yang beradaptasi dengan covid 19 dan tetap melakukan gaya hidup sehat (Disaster: COVID-19 outbreak, Before: disseminating information about the Covid 19 disease to the public, both the symptoms, how to prevent the infection and the risks or dangers of Covid 19, When: making efforts to prevent or break the chain of the spread of Covid 19, by adopting a healthy lifestyle, reducing activities in outside the home or gathering in public places, washing hands frequently, wearing a mask when leaving the house and participating in helping fight and overcoming covid 19 by providing material and non-material assistance, After: continuing to strive to prevent the spread of covid 19, adopting a lifestyle that adapts to covid 19 and continue to live a healthy lifestyle)".

For answers regarding earthquake disaster mitigation procedures are as follows:

RPC_015 answered: "Bencana: gempa bumi, sebelum terjadi gempa bangun rumah anti gempa, siapkan kotak p3k kemudian pelajari jalur evakuasi, saat terjadi gempa misal didalam rumah cari tmpt berlindung yg kokok seperti dibawah meja, kalau diluar cari lapangan hindari pohon dan tiang listrik pastikan tanah yg dipijak tidak terjadi erosi dan setelah gempa keluar dari ruangan cari informasi gempa jangan kembali keruangan setelah gempa (Disaster: earthquake, before the earthquake, build an earthquake-proof house, prepare a first aid kit then study the evacuation route, when an earthquake occurs, for example, in the house, look for a shelter that crows like under a table, if outside, look for a field, avoid trees and electric poles, make sure the ground you are stepping on is not erosion occurs and after the earthquake leaves the room looking for earthquake information do not return to the room after the earthquake)".

RPC_030 answered: "Mitigasi Bencana: Gempa Bumi. Sebelum Gempa: Mendirikan bangunan sesuai aturan baku (tahan gempa) Kenali lokasi bangunan tempat Anda tinggal, tempatkan perabotan pada tempat yang proporsional, siapkan peralatan seperti senter, $P_{3} K$, makanan instan, dll. Periksa penggunaan listrik dan gas, catat nomor telepon penting, kenali jalure evakuasi, ikuti kegiatan simulasi mitigasi bencana gempa. Ketika Gempa: Tetap tenang, hindari sesuatu yang kemungkinan akan roboh, kalau bisa ke tanah lapang, perhatikan tempat Anda berdiri, kemungkinan ada retakan tanah, turun dari kendaraan dan jauhi pantai. Setelah Gempa: Cepat keluar dari bangunan, gunakan tangga biasa, periksa sekitar Anda, jika ada yang terluka, lakukan pertolongan pertama, hindari banugnan yang berpotensi roboh (Disaster Mitigation: Earthquakes. Before the Earthquake: Build buildings according to standard rules (earthquake resistance). Know the location of the building where you live, place the furniture in a proportional place, prepare equipment such as flashlights, first aid kits, instant food, etc. Check electricity and gas usage, record important telephone numbers, identify evacuation routes, participate in earthquake disaster mitigation simulation activities. During an Earthquake: Stay calm, avoid anything that might collapse, if possible go to the field, pay attention to where you are standing, there may be ground cracks, get off the vehicle and stay away from the beach. After the Earthquake: Quickly get out of the building, use ordinary stairs, check your surroundings, if anyone is injured, do first aid, avoiding potentially collapsing buildings)".

The answers to the volcano disaster mitigation procedures are as follows:

RPC_057 answered: "Meletus Gunung Merapi. Sebelum: Selalu memantau status gunung merapi, jika sudah diketahui akan meletus segera mengikuti perintah petugas. Saat: Mengikuti arah petugas segera bergegas menjauhi gunung merapi berjalan menjauhi arah angin karena akan keluar abu vulkanik, memakai masker serta bersama keluarga mengungsi membawa barang yang sangat penting. Setelah:Pantau informasi kemudia tetap memakai masker jauhi dulu daerah yang terkena abu vulkanik jika sudah ada dari petugas sdh bisa untuk kembali ke rumah kemudian membersihkan atap yang terkena abu"(Mount Merapi erupts. Before: Always monitor the status of Mount Merapi, if it is known that it will erupt immediately follow the officer's orders. When: Following the direction, the officers immediately rushed away from Mount Merapi, walking away from the wind because volcanic ash would come out, wearing masks and with their families evacuating very important items. After: Monitor the information then keep wearing a mask first stay away from areas affected by volcanic ash if there are already available from the officers, they can return home then clean the roof affected by ash)".

Respondents who do not know disaster mitigation procedures are as follows: 
RPC_055 answered: "Bencana alam, sebelum terjadi bencana, saat terjadi bencana dan setelăh terjadinya bencana (Natural disasters, before a disaster occurs, during a disaster and after a disaster)".

Respondents' responses to disaster management procedures have seen in Table 3 below.

Table 3. Respondents' Responses on Disaster Management Procedures

\begin{tabular}{llcc}
\hline $\begin{array}{c}\text { Respondents' } \\
\text { Answers }\end{array}$ & \multicolumn{1}{c}{ Respondents' Answers Classification } & Count & Percentage \\
\hline Yes & Forest fire mitigation procedures & 3 & $4,35 \%$ \\
\cline { 2 - 4 } & Flood mitigation procedures & 32 & $46,38 \%$ \\
\cline { 2 - 4 } & Tsunami mitigation procedures & 1 & $1,45 \%$ \\
\cline { 2 - 4 } & Landslide mitigation procedures & 5 & $7,25 \%$ \\
\cline { 2 - 4 } & Covid-19 mitigation procedures & $\mathbf{1 4}$ & $4,35 \%$ \\
\cline { 2 - 4 } & Earthquake mitigation procedures & $\mathbf{1}$ & $\mathbf{1}, 45 \%$ \\
\cline { 2 - 4 } & Volcano mitigation procedures & 9 & $1,45 \%$ \\
\cline { 2 - 4 } & Not knowing disaster mitigation procedures & $\mathbf{1 3 , 0 4 \%}$ \\
\hline No & Does not provide answers to disaster mitigation procedures & $\mathbf{6 9}$ & $\mathbf{1 0 0 , 0 0 \%}$ \\
\hline Number of Respondents & &
\end{tabular}

Based on table 3 above, to find out to what extent the respondent's knowledge of disaster mitigation knowledge about disaster management procedures with the respondent's answer is yes or no. The number of answers to yes was 60 people, and the answer was not nine people. The knowledge of prospective elementary school teachers about forest fire mitigation procedures amounted to three people with a percentage of $4.35 \%$. Knowledge of flood mitigation procedures totalled 32 people, with a percentage of $46.38 \%$. Knowledge of tsunami disaster mitigation procedures is one person with a percentage of $1.45 \%$. There were five people with knowledge of landslide mitigation procedures with a percentage of $7.25 \%$. Knowledge of covid-19 disaster mitigation procedures amounted to 3 people with a percentage of $4.35 \%$. Knowledge of earthquake disaster mitigation procedures totalled 14 people, with a percentage of $20.29 \%$. Knowledge of volcano disaster mitigation procedures is as much as one person with a percentage of $1.45 \%$. Meanwhile, the number of respondents who did not know disaster mitigation procedures was one person with a percentage of $1.45 \%$. Moreover, nine respondents who did not provide answers about disaster mitigation procedures is $13.04 \%$.

Regarding the knowledge aspect, prospective school teachers explaining disaster management procedures have provided answers about various disaster management procedures. The classification of disaster management procedures from respondents' answers consists of forest fire, flood, tsunami, landslide disaster mitigation procedures, covid-19 disaster mitigation procedures, earthquake disaster mitigation procedures, and mountain mitigation procedures from respondents' answers fire. It proves that prospective teachers are cognitively able to mention disaster management procedures. The most frequently mentioned disaster management procedure is flood disaster management because most respondents live in coastal areas and waters.

Primary school teachers' knowledge about disaster mitigation, natural disasters, nonnatural disasters, and social disasters is very much needed (Oktari et al., 2018). Disaster mitigation education needs to be applied in schools to determine students' preparedness in the face of disasters (Metalin et al., 2020; Noviana et al., 2019; Hayudityas, 2020). Students must know about disaster preparedness and disaster mitigation to prepare prospective elementary school teachers. Preparation of prospective elementary school teachers needs to be done, namely by providing textbooks and teaching materials related to disaster mitigation content (Darmawan et al., 2020; Nouchi et al., 2015), preparing teaching materials and teaching materials (Noviana et al., 2020)(Hamed et al., 2014) for disaster mitigation (Rosmiati et al., 2020) which are given to prospective teacher candidates. Knowledge of the curriculum (Sakurai et al., 2020), especially on 
disaster mitigation education in elementary schools (Pambudi, 2018). In addition, the most important thing is to provide various competencies (Selvi, 2010)(Liakopoulou, 2011) to prospective teachers, namely: attitudes; skills and knowledge; degree or level of ability based on the assessment of others (Kawasaki et al., 2020); and characteristics possessed by a teacher (Prasertcharoensuk et al., 2015). So, it is hoped that someday, becoming a teacher has a role in educating students to achieve their competence. In addition, facilitators must ensure that the quality of performance and performance in good teaching is essential for teachers (Ridwan, 2019). Therefore, teachers' roles are essential factors essential for prospective elementary school teachers to learn (Asfani et al., 2016).

\section{CONCLUSION}

The knowledge of disaster mitigation for elementary school teacher candidates is quite good as seen in (a) knowledge of the term disaster mitigation, students of prospective elementary school teachers can understand the term disaster mitigation as an effort to reduce or minimize risks and disaster impact; (b) knowledge of disaster mitigation regarding types of disasters, student prospective elementary school teachers can mention the types of disasters both natural and nonnatural disasters; and (c) knowledge of disaster mitigation on disaster management procedures, student elementary school teacher candidates can mention disaster management procedures. Disaster management procedures are mostly flood management procedures. Limitations in this study include not describing the performance of teaching about disaster mitigation content by prospective elementary school teachers. Therefore, further research is about teaching about disaster mitigation content by prospective elementary school teachers. The research implication is that the knowledge on the mitigation of elementary school teacher candidates is quite good; this can enable prospective teachers to know disaster mitigation, which can later be transferred back to students.

\section{REFERENCES}

Akbar, A., Hadi, R., \& Sabarudin, M. S. (2011). Studi Sumber Penyebab Terjadinya Kebakaran dan Respon Masyarakat dalam Rangka Pengendalian Kebakaran Hutan Gambut di Areal Mawas Kalimantan Tengah. Jurnal Penelitian Hutan Tanaman, 8(5), 287-300. https://doi.org/https://doi.org/10.20886/jpht.2011.8.5.287-300.

Ardiansyah, A. D. (2017). SMAN Muhammadiyah Toboali 121. Jurnal Pendidikan Geografi: Pendidikan Dan Ilmu Geografi, 22(2), 121-134. https://doi.org/http://dx.doi.org/10.17977/um017v22i22017p121

Asfani, K., Suswanto, H., \& Wibawa, A. P. (2016). Influential factors of students' competence. World Transactions on Engineering and Technology Education, 14(3), 416-420.

Creswell, J. W. (2010). Research design pendekatan kualitatif, kuantitatif, dan mixed. Yogyakarta: Pustaka Pelajar

Darmawan, E., Prajoko, S., Nurhikmahyanti, D., Wicaksono, A. B., \& Pamungkas, M. D. (2020). Buku Perkuliahan Mitigasi Bencana: Memberdayakan Karakter Dan Keterampilan Berpikir Kritis Mahasiswa Universitas Tidar. Alpen: Jurnal Pendidikan Dasar, 4(1), 17-29. https://doi.org/10.24929/alpen.v4i1.37

Fadilah, M., Maryani, E., Riandi, R., \& Permanasari, A. (2021). Faktor-faktor Kesiapsiagaan Bencana Terintegrasi Pengetahuan Prekursor Gempa Bumi pada Mahasiswa Pendidikan IPA. Jurnal Pendidikan Geografi, 26(1), 1-14. https://doi.org/10.17977/umo17v26i12021poo1.

Government Regulation of the Republic of Indonesia Number 24 of 2007. (online) https://bnpb.go.id/ppid/file/UU_24_2007.pdf.

Haddow, G. D, \& Kims. (2008). Disaster Communications, In A Changing Media World. London. Burlington USA. Butterworth-Heinemann.

Hamed, R., Azri, A., \& Al-rashdi, M. H. (2014). The Effect Of Using Authentic Materials In Teaching. International Journal of Scientific \& Technology Research, 3(10), 249-254.

Hayudityas, B. (2020). Pentingnya Penerapan Pendidikan Mitigasi Bencana di Sekolah untuk Mengetahui Kesiapsiagaan Peserta Didik. Journal Edukasi Nonformal, 1(21), 94-102. 
https://doi.org/10.1016/j.tmaid.2020.101607.

Kastolani, W., \& Mainaki, R. (2018). Does Educational Disaster Mitigation Need To Be Introduced In School? SHS Web of Conferences, 42, 00063. https://doi.org/10.1051/shsconf/20184200063.

Kawasaki, H., Yamasaki, S., Rahman, M. M., Murata, Y., Iwasa, M., \& Teramoto, C. (2020). Teachers-parents Cooperation in Disaster Preparation when Schools become as Evacuation Centers. International Journal of Disaster Risk Reduction, 44(May 2019), 101445. https://doi.org/10.1016/j.ijdrr.2019.101445.

Liakopoulou, M. (2011). The Professional Competence of Teachers: Which qualities, attitudes, skills, and knowledge contribute to a teacher's s effectiveness ? International Journal of Humanities and Social Science, 1(21), 66-78.

Mahmoud, E. A., \& Auter J. P. (2009). The Interactive Nature of Computer-Mediated Communication. American Communication Journal Vol. 11 No.4. Hal. 19-21.

Metalin, A., Puspita, I., Guru, P., \& Dasar, S. (2020). Metacognitive Analysis of Elementary School Students. International Journal of Elementary Teacher Education (IJETE), 1(1), 1-8.

Moleong, L. (2010). Metodologi penelitian kualitatif (edisi revisi). Bandung: PT Remaja Rosdakarya

Mushtaq, I., \& Khan, S. N. (2012). Factors Affecting Students' Academic Performance. Global Journal of Management and Business Research, 12(9).

Nouchi, R., Sato, S., \& Imamura, F. (2015). Disaster education for elementary school students using disaster prevention pocket notebooks and quizzes. Journal of Disaster Research, 10(6), 1117-1125. https://doi.org/10.20965/jdr.2015.p1117.

Noviana, E., Kurniaman, O., \& Affendi, N. (2020). KOASE: Disaster Mitigation Learning Media in Elementary School. Tadris: Jurnal Keguruan Dan Ilmu Tarbiyah, 5(1), 11-25. https://doi.org/10.24042/tadris.v5i1.5183.

Noviana, E., Kurniaman, O., Munjiatun, Nugraheti Sismulyasih, S. B., \& Nirmala, S. D. (2019). Why do Primary School Students Need Disaster Mitigation Knowledge? (Study of the Use of Koase Comics in Primary Schools). International Journal of Scientific and Technology Research, 8(11), 216-221.

Oktari, R. S., Shiwaku, K., Munadi, K., Syamsidik, \& Shaw, R. (2018). Enhancing community resilience towards disaster: The contributing factors of the school-community collaborative network in the tsunami-affected area in Aceh. International Journal of Disaster Risk Reduction, 29, 3-12. https://doi.org/10.1016/j.ijdrr.2017.07.009.

Pambudi, D. I. (2018). Integrating Disaster Mitigation Education in the Elementary School Curriculum. Advances in Social Science, Education, and Humanities Research (ASSEHR), 147(Icsse 2017), 79-82. https://doi.org/10.2991/icsse-17.2018.19.

Prasertcharoensuk, T., Somprach, K., \& Ngang, T. K. (2015). Influence of Teacher Competency Factors and Students' Life Skills on Learning Achievement. Procedia - Social and Behavioral Sciences, 186, 566-572. https://doi.org/10.1016/j.sbspro.2015.04.021.

Ridwan, A. (2019). Persepsi Resiko Pencegahan Bencana dan Penampilan Guru SD dalam Mengurangi Dampak Bencana Gempa. JIM FKep, IV(2), 42-47.

Rosmiati, R., Liliasari, L., Tjasyono, B., Ramalis, T. R., \& Satriawan, M. (2020). Adaptasi dan Mitigasi Bencana Alam untuk Mahasiswa Calon Guru Fisika Melalui Pengembangan LKM. Jurnal Penelitian Pembelajaran Fisika, 11(1), 1-8. https://doi.org/10.26877/jp2f.v11i1.5272.

Sakurai, A., Sato, T., \& Murayama, Y. (2020). Impact evaluation of a school-based disaster education program in a city affected by the 2011 great East Japan earthquake and tsunami disaster. International Journal of Disaster Risk Reduction, 47(March), 101632. https://doi.org/10.1016/j.ijdrr.2020.101632.

Sari, D. N. (2017). The Analysis of Policy Directions of Geography Teacher's Professional Competence in Mastering Natural Disaster Adaptation and Mitigation Materials in State Senior High Schools in Lubuk Linggau City. Sumatra Journal of Disaster, Geography and Geography Education, 1(2), 298. https://doi.org/10.24036/sjdgge.v1i2.53.

Selvi, K. (2010). Teachers' competencies. Cultura. International Journal of Philosophy of Culture and Axiology, 7(1), 167-175. https://doi.org/10.5840/cultura20107133

Sumarni, W., Wardani, S., Sudarmin, S., \& Gupitasari, D. N. (2016). Project-Based Learning (PBL) to Improve Psychomotoric Skills: A Classroom Action Research. Jurnal Pendidikan IPA Indonesia, 5(2), 157-163. http://dx.doi.org/10.15294/jpii.v5i2.4402. 
Sugiyono. (2015). Metode Penelitian Pendidikan. Bandung: Alfabeta.

Tuswadi, \& Hayashi, T. (2014). "Disaster Prevention Education in Merapi Volcano Area Primary Schools: Focusing on Students' Perception and Teachers' Performance." Procedia Environmental Sciences 20:668-77.

Utaminingsih, A., \& Hakim, M. L. (2015). Disaster Mitigation Strategy at Local Level : Study of Disaster Mitigation Strategy at Malang District, East Java, Indonesia. Public Policy and Administration Research, 5(9), 135-141. www.iiste.org

Weichselgartner, J, \& Patrick, P. (2015). "The Role of Knowledge in Disaster Risk Reduction." International Journal of Disaster Risk Science 6(2):107-16.

Widowati, E., Istiono, W., \& Husodo, A. H. (2021). The Development of Disaster Preparedness and Safety School Model: A Confirmatory Factor Analysis. International Journal of Disaster Risk Reduction, 53, 102004. https://doi.org/10.1016/j.ijdrr.2020.102004

Winkellmann, S. (ed). (2012). The Social Media (R)evolution? Asian Perspectives On New Media. Singapore. Konrad-Adenauer-Stiftun

Ye, Y., De Moortel, K., \& Crispeels, T. (2020). Network Dynamics of Chinese University Knowledge Transfer. Journal of Technology Transfer, 45(4), 1228-1254. https://doi.org/10.1007/s10961-019-09748-7

Yustina, Oesman, K., \& Meerah, T.S. (2010). Innovative Approach Inculcating Positive Attitudes and Students Involvement towards Environment in Biology Classroom. Procedia Social and Behavioral Sciencedirect, 2, 3775-3779.

Yustina, \& Kaspin. (2017). The Implementation of Constructivism-Based Student Worksheets Within The Theme 'The Prevention of Land And Forest Fire' In Science Education For Seventh Graders In Riau. Jurnal Pendidikan IPA Indonesia, 6 (2), 298-305. http://dx.doi.org/10.15294/jpii.v6i2.10573. 